\author{
Nikša Minić \\ Voltićeva 16, HR-52100 Pula \\ niksa.minic@gmail.com
}

\title{
Nadvojvoda Karlo Stjepan na Jadranu
}

\author{
Pregledni rad | Review \\ UDK 929.731 Habsburg, K.S. \\ Primljeno | Received: 1. XII. 2013.
}

\section{Izvadak}

Sredinom 19. stoljeća međunarodna europska politika primorala je Habsburšku Monarhiju na jačanje vojnopomorskih snaga na istočnom Jadranu. Izravna je posljedica toga bio početak razvoja ratne luke Pule koja doživljava modernizacijski, kulturni i društveni uspon. Ubrzo njezini žitelji postaju ljudi iz visokih društvenih krugova s područja Monarhije, a među njima i nadvojvoda Karlo Stjepan Habsburški. Na temelju dostupne arhivske građe i literature prikazan je dio nadvojvodina života, tj. njegova mornarička karijera u kojoj je napredovao do najvišega časničkog čina, zatim njegova ljubav prema krstarenju Jadranom te pojedinosti tijekom njegova boravka u Puli i Velom Lošinju. Bit će i riječi o političkim okolnostima koje su zadesile nadvojvodu i na trenutak ga stavile na pozornicu svjetskih zbivanja.

\begin{abstract}
In the mid-19 $9^{\text {th }}$ century, international European politics forced Habsburg Monarchy to strengthen their naval forces in the East of the Adriatic Sea. The result was the beginning of the development of naval port Pula which in turn saw more modern, cultural and social rise. Soon members of high class from all over Monarchy became its residents; among them was Archduke Charles Stephen of Austria. A part of Archduke's life has been reconstructed based on available documents from the archives and the literature, namely, his naval career which saw him rising to the highest ranking officer, then his love of sailing the Adriatic, as well as certain details about his stay in Pula and Veli Lošinj. Political circumstances which had put the Archduke on the map of world history shall be mentioned as well.
\end{abstract}

Ključne riječi: nadvojvoda Karlo Stjepan, krstarenje na Jadranu, austro-ugarska ratna mornarica, pobuna mornara u Boki kotorskoj

Key words: Archduke Charles Stephen, sailing the Adriatic, Austro-Hungarian navy, mutiny of sailors in Boka Kotorska 


\section{Uvod}

U drugoj polovici 19. stoljeća počele su se mijenjati okolnosti na europskoj međunarodnoj sceni. Habsburška Monarhija suočila se sa svojim najvećim izazovom dotad - nacionalizmom, koji joj je na unutarnjem političkom planu prijetio rastućom težnjom pojedinih pripadnika različitih naroda unutar Monarhije za nacionalnim samoodređenjem i stvaranjem nacionalnih država. Iako je uspjela smiriti unutarnje turbulencije izazvane nizom revolucija koje su je zatekle 1848./1849. i tako osigurati svoj opstanak, na vanjskopolitičkom se planu nekadašnja vodeća diplomatska sila staroga kontinenta morala pomiriti s gubitkom utjecaja u nekim dijelovima Europe. Tijekom rata za ujedinjenje Italije prvo je potisnuta iz Lombardije 1859., a sedam godina poslije i s područja nekadašnje Mletačke Republike, čime je izgubila svoje posjede na zapadnoj obali Jadrana. Posljedica je tih događaja bila odluka da se znatno veća sredstva usredotoče na učvršćivanje vojnopomorskih položaja na istočnoj jadranskoj obali.

Proces učvršćivanja položaja na istočnom Jadranu započeo je već nešto prije, kada je austrijska vlast, potaknuta aspiracijama talijanskoga nacionalnog pokreta prema području nekadašnje Mletačke Republike, počela razmišljati o gradnji nove ratne luke. Mladi car Franjo Josip I. odlučio je ne slušati savjete starijih austrijskih generala, nego je na preporuku viceadmirala Danca Hansa Bircha Dahlerupa (1790. - 1872.) 1853. Pulu proglasio novom ratnom lukom Monarhije. ${ }^{1}$ Bio je to početak nagloga razvoja grada. Tri godine poslije car je osobno sudjelovao u postavljanju temeljnoga kamena za izgradnju Pomorskoga arsenala, iako su neki njegovi dijelovi, poput radionice za popravak brodova, već bili izgrađeni. ${ }^{2}$

Pula je 40-ih i 50-ih godina 19. stoljeća bila grad u ruševinama ograđen zidinama koje su sprječavale cirkulaciju ljudi i roba te pomagale širenje malarije. Međutim, uskoro se počinju javljati prve skice i planovi za izgradnju mornaričkih objekata koji će nesumnjivo obogatiti i proširiti gradsku infrastrukturu. Do 1866. završena je izgradnja mornaričke vojarne, mornaričke bolnice, nekoliko dvokatnih zgrada za stanovanje pripadnika mornarice te zgrade Zapovjedništva mornarice. ${ }^{3}$ Prestiž grada koji se nalazio u stalnom porastu učvršćen je poslije Viške bitke 1866., kada je pobjeda nad

\footnotetext{
Darko Dukovski, Povijest Pule, Pula 2011., 112.

Mate Balota, Puna je Pula, Pula 2005., 43.

Isto, 44.
} 
talijanskom flotom pokazala isplativost odluke ulaganja u mornaricu i donijela mir na Jadranu za sljedećih više od četrdeset godina.

Poslije Viške bitke započinje nagli razvoj izgradnje u Puli. Između 1870. i 1880. prosječno je na godinu građeno pedeset novih kuća, a sličan je prosjek zadržan i u narednom desetljeću. ${ }^{4}$ Građene su i kuće za mornaričke časnike i dočasnike. Oni su bili dio vojnoga stanovništva koje je raslo usporedno s gradnjom ratne luke i porastom broja mornaričkoga osoblja. Potreba za opskrbom stalno rastućega stanovništva otvorila je vrata trgovini, obrtima, ugostiteljstvima te slobodnim zanimanjima.

Nakon izgradnje Arsenala u grad su se sve više doseljavali časnici i drugi pripadnici Ratne mornarice te radnici s područja cijele Monarhije koji će se za nekoliko godina s pravom moći nazvati građanima Pule. Potaknuti gradnjom Arsenala, u grad su pristizali i stanovnici ruralnih krajeva Istre, ali i drugih krajeva Monarhije pa je broj gradskoga stanovništva konstantno rastao. Primjerice, 1880. samo su 21,38 \% stanovnika bili starosjedioci, 32,92 \% su bili doseljeni s područja Istre, a 29,83\% stanovnika bili su građani drugih pokrajina Cislajtanije. S područja Translajtanije je dolazilo 8,20 \%, a iz drugih krajeva Europe 7,67 \% stanovnika. ${ }^{5}$ To pokazuje kako je Pula nakon arhitektonskoga i urbanističkoga uspona postala mjesto boravka pripadnika srednjoeuropskih naroda postajući tako moderan europski i kozmopolitski grad. Osim gradnje vojnih objekta gradili su se i oni kulturni, poput kazališta Teatro Nuovo (1851. - 1854.), staroga mornaričkog kasina (1872.), novoga kazališta Politeama Ciscutti (1881.), javnoga kupališta (1885.) i gradske tržnice (1889.). Ove su kulturne građevine pored brojnih parkova i šetnica davale Puli kozmopolitski srednjoeuropski ugođaj. Samim time, Pula je s okolicom postala dom, makar i privremeni, za osobe visokoga društvenog položaja, poput bogatoga industrijalca Paula Kupelwiesera, a grad su posjećivali car Franjo Josip I., njegov nesuđeni nasljednik carević Rudolf i ostali pripadnici dinastije Habsburg. Pula je također bila boravište pojedinaca koji su kasnije postali poznati i utjecajni. Spomenut ćemo Miklósa Horthyja, mornaričkoga časnika koji je pred kraj Prvoga svjetskog rata imenovan vrhovnim zapovjednikom austro-ugarske mornarice, da bi ga kasniji razvoj događaja doveo na položaj mađarskoga regenta, i Jamesa Joycea, koji je u Puli kratko vrijeme bio nastavnik engleskoga jezika, da bi

$4 \quad$ Isto, 46.

5 Dukovski, Povijest Pule, 117. 
se kasnije proslavio svojim romanom Uliks. Među značajnim doseljenicima bio je i jedan mladi austrijski nadvojvoda.

\section{Vojno-politička karijera nadvojvode Karla Stjepana}

Nadvojvoda Karlo Stjepan Habsburški rođen je 5. rujna 1860. u dvorcu u Židlochovicama (Seelowitz) kraj Brna u Moravskoj kao četvrto od ukupno šestero djece austrijskoga nadvojvode Karla Ferdinanda (1818. - 1874.) i nadvojvotkinje Elizabete (1831. - 1903.). Do svoje četrnaeste godine odgajan je u roditeljskom domu, a nakon smrti oca brigu o njemu preuzeo je njegov stric nadvojvoda Albert, koji ga usmjerio na vojničku karijeru. ${ }^{6}$ Dvije godine poslije, točnije 24. travnja 1876., u dobi od šesnaest godina promaknut je u čin poručnika 1. pješačke pukovnije. ${ }^{7}$ Unatoč tome, mladi se nadvojvoda umjesto karijere u kopnenoj vojsci odlučio za mornaričku pa se 1875. upisao u Mornaričku akademiju (Marine-Akademie) u Rijeci, koju završava 3. srpnja 1879., promaknut u čin zastavnika. ${ }^{8}$ Valja napomenuti da je Karlo Stjepan upisao školu u Rijeci kao izvanredni učenik, ali je imao obaveze redovnoga učenika, ${ }^{9}$ te da se na prijemnom ispitu nije iskazao položivši ga s prosječnom ocjenom „zadovoljavajući“.10 Za vrijeme njegova studija i boravka u Rijeci dodijeljen mu je mornarički časnik na obnašanje službe. ${ }^{11}$

Poslije završetka mornaričke akademije, pod „tutorstvom“ tadašnjega kapetana fregate Hermanna von Spauna (1833. - 1919.), ukrcao se na korvetu Saida, na kojoj je od 15. listopada 1879. do 23. srpnja 1880. bio na prekooceanskom putovanju u Brazilu, Zapadnoj Indiji, Južnoj Africi te Sjevernoj Americi (New York). ${ }^{12}$ Bilo je to stručno putovanje za mladoga nadvojvodu, koji unatoč povlaštenom društvenom statusu, tijekom putovanja nije uživao povlašten tretman. Nakon povratka s putovanja i kratkoga boravka na kopnu, Karlo Stjepan je svoje časničko usavršavanje nastavio na kazematnom brodu Custoza, gdje ga je i dalje pratio von Spaun. Poslije

\footnotetext{
6 Antonio Schmidt-Brentano, Die österreichischen Admirale, Band 1: 1808-1895, Osnabrück 1997., 472.

7 Heinrich Bayer von Bayersburg, Österreichs Admirale und bedeutende Persönlichkeiten der k.u.k. Kriegsmarine 1867-1918, Wien 1962., 72.

8 Schmidt-Brentano, Die österreichischen Admirale, 472.

9 Na ist. mj.

10 Nadvojvoda je položio sljedeće predmete: elementarna matematika-dovoljan, geografija-zadovoljavajući, povijest - pohvalno, kemija - zadovoljavajući, njemački jezik - pohvalno, uz koji je još učio i francuski te osnove mađarskoga, češkoga i engleskoga. Schmidt-Brentano, Die österreichischen Admirale, 476, bilj. 2.

11 Na ist. mj.

12 Isto, 474; Bayer von Bayersburg, Österreichs Admirale und bedeutende Persönlichkeiten der k.u.k. Kriegsmarine, 72.
} 
završetka službe na Custozi nadvojvoda je dio travnja 1881. proveo služeći svoj mornarski rok kao Matrose na brodu Proserpina ${ }^{13}$, a pola godine poslije, 26. listopada, promaknut je u čin poručnika bojnoga broda. ${ }^{14} \mathrm{U}$ studenome te godine uspješno je završio tečaj iz topništva za časnike, održan na školskom brodu Novara. Službu je nastavio 1882. ponovno na Saidi, a znanje je dodatno proširio završetkom tečaja o torpedima 1883. godine. Svoje prvo zapovjedno mjesto 23-godišnji nadvojvoda preuzeo je na topovnjači Kerka 4. ožujka 1884. godine. Njegov način zapovijedanja Kerkom ocijenio je tadašnji kontraadmiral Maximilian von Pitner (1833. - 1911.; pisao se i kao Pittner) ističući nadvojvodinu pozornost i odlučnost te hvaleći njegovo razumijevanje za taktičke inovacije. ${ }^{15}$

Poslije povratka s Bliskoga istoka, kamo ga je odvela služba na Kerki, Karlo Stjepan je od početka travnja 1885. bio stacioniran u zapovjedništvu ratne luke Pula (Militärhafenkommando Pola). ${ }^{16}$ Radi modernizacije austrougarske ratne mornarice te je godine u Puli osnovan Mornaričko-tehnički odbor (Marine-technisches Komitee) kao savjetodavno tijelo Mornaričkoga odsjeka pri Ministarstvu rata u Beču za pitanja brodogradnje, strojarstva, tehnologije, hidrografije, navigacije i topništva. ${ }^{17}$ Nadvojvoda Karlo Stjepan je od kolovoza bio uključen u rad odbora doprinoseći svojim znanjem o torpedima. O kvaliteti njegova rada govori podatak da je nekoliko mjeseci poslije (13. svibnja 1886.) ušao u sastav Predsjedništva Mornaričko-tehničkoga odbora (Präsidium), svega trinaest dana prije preuzimanja zapovjedništva na lakoj krstarici Panther 26. svibnja. ${ }^{18} \mathrm{U}$ tom se razdoblju Karlo Stjepan zajedno sa suprugom nadvojvotkinjom Marijom Terezijom već bio preselio u Pulu.

Nakon dva mjeseca, koliko je proveo zapovijedajući Pantherom, ponovno je u srpnju preuzeo mjesto u Predsjedništvu Mornaričko-tehničkoga odbora. Tri mjeseca poslije promaknut je u čin kapetana fregate, a sredinom siječnja 1887. čini dio Stožera pulskoga Pomorskog arsenala (Seearsenalkommando Pola). Bilo je uobičajeno da se na zapovjednim položajima Arsenala nalaze pomorski časnici koji su završili Mornaričku akademiju i

\footnotetext{
13 Branko Perović, Austrougarske vile i kuće u Puli, Pula 2010., 19; Schmidt-Brentano, Die österreichischen Admirale, 472

14. Schmidt-Brentano, Die österreichischen Admirale, 472.

15 Isto, 472,475 .

16 Isto, 475 .

17 Dario Petković, Ratna mornarica Austro-Ugarske Monarhije, Pula 2004., 25.

18 Schmidt-Brentano, Die österreichischen Admirale, 472.
} 
tako stekli opće ratno i navigacijsko znanje, ali su pored toga imali završene specijalne tečajeve (najmanje jedan, a najviše tri) iz topništva, minerstva i torpeda. ${ }^{19}$ Pola godine potom postaje zapovjednikom na topovnjači Hum, a u travnju se 1888. vraća u Pulu, gdje u pomorskoj bazi ulazi u sastav časnika zaduženih za nadopunu osoblja flote. Karlo Stjepan će u pomorskoj bazi, uz povremene prekide, gotovo punih šest godina obnašati ovu dužnost, a potom će jednaku dužnost preuzeti u Lučkom admiralitetu (Hafenadmiralat Pola). ${ }^{20}$

U međuvremenu je u lipnju 1888. preuzeo zapovjedno mjesto na lakoj krstarici Tiger obnašajući ujedno dužnost zapovjednika cijele torpedne flotile. Dvije godine poslije zapovijedao je mornaričkim korpusom, a u travnju je te 1890. promaknut u čin kapetana bojnoga broda. Nakon tri mjeseca postao je zapovjednikom teške krstarice Kaiser Franz Joseph I. ${ }^{21} \mathrm{O}$ časničkim osobinama koje su krasile Karla Stjepana svjedoče dvije izjave njegovih pretpostavljenih von Sternecka i Heinza. Viceadmiral Maximilian Daublebsky von Sterneck (1829. - 1897.)22 službeno je 1887. ocijenio Karla Stjepana kako ima sve karakteristike školovanoga mornara, ali da se kao zapovjednik još mora dokazati. Dvije godine poslije Julius Heinz (1839. - 1909.) ocijenio je nadvojvodu kao čovjeka razvijenih radnih navika, koji svaki dan u svoj posao ulaže mnogo ljubavi i razumijevanja. Ističe njegovu težnju za poboljšanjem u pomorsko-tehničkim elementima. ${ }^{23}$ Činjenica da je nadvojvodi dodijeljeno zapovjedništvo na svim brodovima klase Panther, tj. torpednim krstaricama Panther, Leopard i Tiger, koje su bile netom izgrađene kao zamjena za torpedne brodove klase Zara, govori kako je nadvojvoda svojim načinom rada skrenuo pozornost na sebe i počeo uživati veliko povjerenje nadređenih.

Početkom svibnja 1891., nakon što je gotovo pola godine radio u pulskoj vojnopomorskoj bazi, ponovno je preuzeo zapovjedništvo na krstarici Kaiser Franz Joseph I., na kojoj je proveo dva mjeseca. Sljedeće godine zapovijedao je oklopnjačom Don Juan d'Austria. ${ }^{24}$ Bilo je tada već jasno da će nadvojvoda početi dobivati sve veću odgovornost, a samim time i viši čin. Prvo je od rujna 1893. do travnja 1894. zapovijedao divizijom brodova

19 Balota, Puna je Pula, 72.

20 Schmidt-Brentano, Die österreichischen Admirale, 472.

$21 \mathrm{Na}$ ist. mj.

22 Admiral od 1888. godine. Najzaslužniji je za početak izgradnje pulske Mornaričke crkve, u kojoj je pokopan nakon smrti, ali nije doživio završetak njezine izgradnje.

23 Schmidt-Brentano, Die österreichischen Admirale, 475.

24 Isto, 473. 
dobivši u međuvremenu čin kontraadmirala. Krajem travnja 1894. preuzima zapovjedništvo nad divizijom krstarica i flotom torpiljarki prilikom izvođenja ljetnih vježbi eskadre, da bi nakon njihova završetka dobio zapovjedništvo nad teškom divizijom bojnih brodova. Iduće godine, kao zapovjednik divizije brodova, prisustvovao je otvaranju Kielskoga kanala. ${ }^{25}$ Posljedica je to velikoga poštovanja koje je njemački car Vilim II. osjećao prema nadvojvodi čija je pomorska karijera gotovo dosegla vrhunac. O njegovom napretku govore službene ocjene njegovih pretpostavljenih, von Hinkea, von Pitnera i von Spauna. Johann von Hinke (1837. - 1904.) govori o Karlu Stjepanu kao o pomorcu s izraženim osjećajem za pomorstvo kojega krase mirnoća i odlučnost, dok je von Pitner smatrao nadvojvodu dobrim primjerom posadi, dodajući kako ga u službi krase nepokolebljivost i težnja da doprinese nečim izvanrednim. Njegov nekadašnji „tutor“ von Spaun tada je smatrao da je Karlo Stjepan spreman za viši položaj i odgovornost. ${ }^{26}$

Međutim, 1896. se godine Karlo Stjepan povukao iz aktivne službe nakon što je poslije smrti strica, nadvojvode Alberta, naslijedio obiteljsko imanje u Galiciji. Unatoč tome, nastavio je napredovati u službi te je 1911. stekao čin admirala. ${ }^{27}$ Početkom 1915. preuzeo je od svojega brata, nadvojvode Eugena (1863. - 1954.), funkciju pokrovitelja dobrotvornih udruga za prikupljanje pomoći u ratu, koju je vodio i nakon promjene na austro-ugarskom prijestolju, kao zamjenik novoga cara Karla (1887. - 1922.) kao pokrovitelja spomenutih udruga. U veljači 1918. car ga je imenovao posebnim povjerenikom za istragu pobune mornara u Boki kotorskoj. Obnašajući ovu dužnost, nadvojvoda je ispitivanjem mlađih časnika o njihovim utiscima, situaciji i uzrocima pobune mornara stekao spoznaju o lošim socijalnim uvjetima koji su vladali u austro-ugarskoj mornarici. Na njegov je prijedlog car Karlo smijenio Maksimilijana Njegovana (1858. - 1930.) i imenovao Miklósa Horthyja (1868. - 1957.) vrhovnim zapovjednikom mornarice. ${ }^{28}$ Zaključak istrage Karla Stjepana bio je da se zapovjedni vrh mora pomladiti. Godine Miklósa Horthyja nisu bile velik problem (imao ih je tada 49), ali njegov čin kapetana bojnoga broda upućivao je na to kako možda ima iskusnijih, spremnijih i više rangiranih časnika za preuzimanje zapovjed-

\footnotetext{
25 Isto, 475.

$26 \mathrm{Na}$ ist. mj.

27 Lawrence Sondhaus, The Naval Policy of Austria-Hungary 1867-1918. Navalism, Industrial Development and the Politics of Dualism, West Lafayette 1994., 135-136.

$28 \mathrm{Na}$ ist. mj.
} 
ništva nad flotom austro-ugarske ratne mornarice. Horthyjevo imenovanje vrhovnim zapovjednikom posljedica je nadvojvodina prijedloga i careve spremnosti da tu preporuku prihvati i provede u djelo. ${ }^{29}$

Rješavanje poljskoga pitanja, jednoga od središnjih političkih problema tijekom Prvoga svjetskog rata, izbacilo je nadvojvodu Karla Stjepana u prvi plan međunarodne politike. Njemački car Vilim II. imao je plan obnoviti Poljsku u slučaju pobjede Središnjih sila kao zemlju usko povezanu s Njemačkim Carstvom. ${ }^{30}$ Stanje na bojištu dopustilo mu je da o tom planu sve intenzivnije razmišlja. Zbog suradnje na otvaranju Kielskoga kanala te velikoga poštovanja koje je gajio prema njemu, kao i zbog činjenice da je Karlo Stjepan tečno govorio poljski te povremeno boravio u svom dvorcu u Żywiecu (Saybusch) u Galiciji, njemački je car u kolovozu 1918. ponudio austrijskom nadvojvodi poljsku krunu. ${ }^{31}$ Za razliku od svojega kolege Horthyja, Karlo Stjepan je odlučio da se ne upušta u političke vode i odbio ponudu Vilima II. s obrazloženjem da je stigla prekasno. I jest. Upravo su u kolovozu te godine vojske sila Antante počele ostvarivati ključnu prednost u ratu, a među Četrnaest točaka američkoga predsjednika Woodrowa Wilsona našle su se i one o obnovi poljske države i pravu naroda na samoodređenje. Time su Poljaci dobili najboljega mogućeg saveznika, a ideja Vilima II. o njihovom povezivanju sa Središnjim silama više nije bila ostvariva. ${ }^{32}$ Karlo Stjepan je odbio poljsku krunu kako zbog većega afiniteta prema mornarici, tako i zbog na vrijeme uočene opasnosti upuštanja u unaprijed izgubljenu borbu koja ga je mogla stajati reputacije, možda čak i života. Nakon završetka Prvoga svjetskog rata ostao je u Poljskoj, u kojoj je posljednje godine života proveo skoro nepokretan zbog posljedica kljenuti živaca. ${ }^{33}$ Umro je 1933. u Żywiecu.

\section{Boravak na Jadranu}

Puno se o Karlu Stjepanu može naučiti iz memoara Nellie Ryan, Engleskinje koja je kao guvernanta provela nekoliko godina na njegovu dvoru. Ona govori o čovjeku izvanrednoga uma, beskonačnoga znanja o nautici, poliglotu koji je tečno govorio engleski, njemački, francuski, poljski, talijanski i mađarski jezik. Bio je vrlo vješt u klizanju, plesu i tenisu, a izraziti je talent iskazivao

29 Christopher M. Bell - Bruce Elleman, Naval Mutinies of the Twentieth Century: An International Perspective, London 2005., 58-59.

30 The History of Poland since 1863, ed. Robert Frank Leslie, Cambridge 1980., 112.

31 Schmidt-Brentano, Die österreichischen Admirale, 475-476.

32 The History of Poland since 1863, 125.

33 Schmidt-Brentano, Die österreichischen Admirale, 475-476. 
slikajući i svirajući klavir. ${ }^{34}$ Znao je pokazivati i svoju drugu stranu prožetu iznenadnim postupcima i pomalo hirovitim ponašanjem te je satima mogao slikati u izoliranom kutu svojega imanja, često i bez jela. Redovito bi ustajao u rane jutarnje sate i, kad mu je vrijeme dopuštalo, otiskivao se svojom jahtom na pučinu gdje je znao provesti nekoliko tjedana slikajući, a njegovi radovi bili su dovoljno kvalitetni da zasluže izložbu u manjim galerijama. ${ }^{35}$

Sklonost prema krstarenju Jadranom nadvojvoda je pokazivao još tijekom obavljanja aktivne mornaričke službe. Godine 1885. krenuo je na krstarenje jadranskom obalom s ciljem pronalaska odgovarajućega mjesta za izgradnju svoje vile. Naposljetku se odlučio za Veli Lošinj, gdje je kupio zemljište i sagradio vilu Wartsee. ${ }^{36}$ Sagradivši je na najljepšem obronku brda Kalvarija, nadvojvoda je pokraj vile dao urediti velik perivoj, jedan od najljepših na istočnoj jadranskoj obali. Perivoj je na nadvojvodu ostavljao jak dojam pa je namjeravao sagraditi i dvorac, ali naposljetku je odustao od gradnje, a prvu vilu i perivoj prodao je $1893 .{ }^{37}$ Bez obzira na to, Veli Lošinj je imao ulogu matične luke nadvojvodinih brodova. Godinu dana nakon kupnje zemljišta u Velom Lošinju, točnije 11. ožujka, nadvojvodi i njegovoj supruzi priređen je svečani doček u Malom Lošinju tijekom kojega se nadvojvoda upleo u problematiku hrvatskoga nacionalnog pokreta. Poštujući program dočeka, Karlo Stjepan se uputio u posjet drugom razredu ženske pučke škole, gdje su mu učenice čitale iz čitanke na talijanskom jeziku. Kad su završile, nadvojvoda je zatražio da čitaju na hrvatskom, koji je smatrao njihovim materinskim jezikom. ${ }^{38}$ Nadvojvodino javno istupanje u malološinjskoj školi (toga je dana zatražio razgovor s ravnateljicom škole i školskim nadzornikom) i priznavanje prava da se hrvatski jezik uči na području naseljenom hrvatskim narodom bio je rijedak slučaj da se vladar ili član vladarske kuće na takav način upliće u nacionalna pitanja i urednici Naše sloge nisu ga propustili prepoznati i pohvaliti. ${ }^{39}$ Važnost nadvojvodina istupa naglasio je i Dinko Vitezić kada je na sjednici Carevinskoga vijeća 8. travnja 1886. govorio o teškom položaju hrvatskoga jezika u istarskim školama. ${ }^{40}$

\footnotetext{
34 Nellie Ryan, My Years at the Austrian Court, London - New York 1915., 75.

35 Isto, 88-89.

36 Julijano Sokolić, Povijest turizma na Lošinju, Mali Lošinj 1997., 10.

37 Isti, „Lošinj i Habsburgovci“, Sušačka revija, 17, 1997., 70.

38 „Različite viesti“, Naša sloga, god. XVII, br. 12 (25. 3. 1886.), 3.

39 „Nadvojvoda Karlo Stjepan i lošinjske škole“, Naša sloga, XVII, 13 (1. 4. 1886.), 1-2.

40 „Govor narodnog zastupnika dra Dinka Vitezića izrečen na sjednici carevinskog vieća dne 8. t. m.“, Naša sloga, XVII, 15 (15. 4. 1886.), 1.
} 
Izabravši grad koji će mu poslužiti kao polazišna točka za krstarenja Jadranom, Karlo Stjepan se potom s obitelji preselio u Pulu. Iako postoji mišljenje da je Pulu izabrao zbog ljubavi prema Pulskom zaljevu s kojim se prvi put susreo 1881. tijekom obnašanja službe, veća je vjerojatnost da je Pulu izabrao zbog službenih razloga, odnosno zbog stupanja u službu u Mornaričko-tehničkom odboru, ali pritom ne bi trebalo isključivati njegov odnos prema Pulskom zaljevu.

Nadvojvoda Karlo Stjepan doplovio je u Pulu s trudnom suprugom Marijom Terezijom na jahti Fantasia 17. travnja 1886. godine. Popularne istarske novine Naša sloga nisu to popratile niti jednom jedinom rečenicom, što ne čudi jer je riječ o listu u kojem su u prvi plan stavljane teme usko vezane uz hrvatski nacionalni pokret s ciljem podizanja i širenja nacionalne svijesti kod istarskih Hrvata. Stoga njegov dolazak, u odnosu na njegov istup u lošinjskoj školi, urednicima Naše sloge nije predstavljao veliku vijest. Nadvojvodi i njegovoj ženi bio je priređen veličanstven doček koji se sastojao iz dva dijela. Prvi se dio odvijao na moru gdje je nadvojvodu, tj. jahtu Fantasia, dočekalo 18 brodica podijeljenih u dvije kolone. Organizatori dočeka su priskrbili odgovarajući broj brodica ponudivši građanima da, ako žele sudjelovati u dočeku (pod uvjetom da imaju brod) podignu u Mornaričkom kasinu crvenu ili bijelu kartu. Brodice s crvenom kartom krenule su u susret nadvojvodi s gata Bellona, a brodice s bijelom kartom s gata Schwarzenberg, kako bi ga pozdravima i glazbom dopratile u unutarnju luku. ${ }^{41}$ Drugi dio svečanoga dočeka odvijao se na kopnu, gdje je ispred zgrade Lučkoga admiraliteta nadvojvotkinji Mariji Tereziji uručen buket uime carsko-kraljevske vojne posade. Nakon toga su par dočekali predstavnici općine na čelu s gradonačelnikom Giovannijem Augustom Wassermannom. ${ }^{42}$ Poslije službenoga prijema Karlo Stjepan i Marija Terezija su ispred Slavoluka Sergijevaca pozdravili učenike općinske škole, a na Danteovu su trgu pozdravili postrojene učenike Mornaričke pučke škole. Organizacijski se odbor zaista potrudio urediti grad kako bi odgovarajuća atmosfera dočekala nadvojvodu i nadvojvotkinju. Dekorativni elementi bili su razasuti gradom, naročito rivom i Danteovim trgom. Posegnuli su čak i

41 Hrvatski državni arhiv u Pazinu, HR-DAPA-40, Općina Pula, kutija 2, II/2 Odredbe o dočeku nadvojvode Karla Stjepana, br. 3339.

42 Marcello Bogneri, Cronache di Pola e dell'Istria 1847-1914. Gli anni della dominazione austroungarica, Trieste 1989., 58-59. 
za insceniranom ovacijom publike u trenutku prolaska nadvojvodskoga para ispred gradske palače. ${ }^{43}$

Nadvojvoda i nadvojvotkinja stigli su u Pulu koja je prolazila kroz fazu izgradnje infrastrukture civilnih i vojnih objekata. Kako u tadašnjoj Puli nije bilo raspoloživoga stambenog objekta predviđenoga za primanje ljudi najvišega društvenog statusa, 1888. je donesena odluka o izgradnji palače u kojoj bi se nadvojvoda s obitelji mogao smjestiti. Umjesto predviđenoga rezidencijalnoga prostora u gradskoj četvrti Sveti Polikarp i na Verudi, kao mjesto izgradnje izabran je centar grada, na prostoru koji se nalazio sučelice Mornaričkom kasinu. ${ }^{44}$ Izgradnja palače trajala je četiri godine, tj. do 9. ožujka 1892., a stajala je sto tisuća forinti. ${ }^{45}$ Druga građevina koja je ugledala svjetlo dana zbog potreba nadvojvode i njegove obitelji jest Vila Idola. Ovaj ljetnikovac je Karlo Stjepan dao izgraditi za svoju najstariju kćer Eleonoru Mariju ${ }^{46}$, udanu za austro-ugarskoga časnika Alfonsa von Klossa. S obzirom na to da prostor na kojem se vila trebala nalaziti nije bio predviđen za gradnju, prije početka radova dobiveno je posebno dopuštenje Lučkoga admiraliteta. ${ }^{47}$

Tijekom života i rada u Puli nadvojvoda je posjećivao kazališne i glazbene priredbe u Mornaričkom kasinu, a u kazalištu Politeama Ciscutti imao je trajno rezerviranu ložu. ${ }^{48}$ Godine 1891. u Puli je pod pokroviteljstvom cara Franje Josipa osnovana Carska i kraljevska jahtaška eskadra (K. $u$. $k$. Yachtgeschwader), najznačajniji nautički klub na teritoriju Austro-Ugarske. Njegovi osnivači i članovi bili su redom osobe visokoga društvenog statusa, nadvojvode, knezovi, pa čak i europski i američki milijunaši. ${ }^{49} \mathrm{Na}$ osnivačkom sastanku kluba 25. srpnja 1891. Karlo Stjepan je imenovan njegovim komodorom, a tu je dužnost obavljao do 1899., kada ga je zamijenio prijestolonasljednik nadvojvoda Franjo Ferdinand. ${ }^{50}$ Veliki zaljubljenik u more i jedrenje, Karlo Stjepan bio je pokrovitelj mnogih jedriličarskih regata, od kojih je najznačajnija bila brijunska Velika regata. ${ }^{51}$

\footnotetext{
43 Hrvatski državni arhiv u Pazinu, HR-DAPA-40, Općina Pula, kutija 2, II/2 Odredbe o dočeku nadvojvode Karla Stjepana, br. 3339.

44. Perović, Austrougarske kuće $i$ vile u Puli, 20.

45 Sergio Zuccoli, „Il quartiere di San Policarpo“, L'Arena di Pola, br. 28 (2-8. 12. 1970.), 438.

46 Eleonora Marija rođena je u Puli, kao i još petero njezine braće i sestara. Jedan se brat zvao Leo Karl Maria Kyrill Method što je interesantan podatak o nadvojvodinoj sklonosti Slavenima u sklopu Monarhije. Schmidt-Brentano, Die österreichischen Admirale, 471.

47 Perović, Austrongarske kuće i vile u Puli, 224-225.

48 Isto, 20.

49 Gordana Tudor, „Strane jahte u splitskoj luci (1890.-1907.)“, Kulturna baština, br. 34, 2007., 144.

50 Schmidt-Brentano, Die österreichischen Admirale, 475.

51 Perović, Austrougarske kuće i vile u Puli, 20.
} 
Tijekom aktivne službe, nadvojvoda je 1893. doplovio u Split na parnoj jahti Christa, a to je ponovio i sljedeće dvije godine. ${ }^{52}$ Napustivši aktivnu službu, nastavio je tijekom svojih krstarenja redovito posjećivati Split, učinivši to 1897. i 1899., u oba navrata doplovivši na svojoj novoj jahti Ossero. ${ }^{53}$ Pri posjetu Splitu 1901. predstavio je svoju novu jahtu Waturus, a 1904. svoj novi škuner Sen. Iste se godine za nadvojvodu u Škotskoj počela graditi Rovenska, jahta duga više od 60 metara, kojom je plovio sve do $1910 .^{54}$ Iako je većina njegovih jahti izgrađena u Engleskoj, nadvojvodin maštovit um imao je velikoga udjela u njihovu dizajnu i planiranju. ${ }^{55}$

Osim krstarenja Jadranom i obaveza prema pulskom nautičkom klubu, nadvojvoda je upravljao imanjem u Żywiecu, koje mu je ostavio u nasljedstvo stric Albert. Ondje je Karlo Stjepan kratio vrijeme slikajući i vrtlarenjem, ali se pokazao i kao dobar poduzetnik unaprijedivši rad pivovare koju je osnovao njegov stric. ${ }^{56}$ Njegovo krstarenje Jadranom trajalo je do izbijanja Prvoga svjetskog rata, kada se opet stavlja u službu Monarhije. ${ }^{57}$

\section{Zaključak}

Nadvojvoda Karlo Stjepan Habsburški samo je jedan od mnogobrojnih članova visokih društvenih krugova čiji se životni put susreo s Pulom tijekom njezina zlatnoga doba. Ljubav prema moru utjecala je na nadvojvodino krstarenje Jadranom, ali i na gradnju vila i palača. U politiku se nije previše miješao, izuzmemo li ionako kratkotrajnu epizodu s mogućnošću primanja poljske krune. Njegov je život pokazao kako je u sebi utjelovio nekoliko različitih osobnosti čija je dodirna točka bila upravo more. Na moru je nadvojvoda bio sposoban mornarički časnik zapovijedajući najmodernijim austro-ugarskim brodovima, bio je plemić sklon krstarenju na svojim velikim i lijepim jahtama, a nerijetko se volio otisnuti na pučinu i slikati okružen valovima. Sudjelovanjem u društveno-kulturnim događajima povećavao je njihov ugled, a volio je pokretati i vlastite, poput brijunske regate. Mjestima u kojima je za svojega života boravio ostavio je raskošne građevine i parkove koji podsjećaju na njihov nekadašnji kozmopolitski status.

\footnotetext{
52 Tudor, „Strane jahte u splitskoj luci“, 147-148.

53 Isto, $149-150$.

54 Isto, 151.

55 Ryan, My Years at the Austrian Court, 81.

56 Schmidt-Brentano, Die österreichischen Admirale, 475.

57 Bayer von Bayersburg, Österreichs Admirale un bedeutende Persönlichkeiten der k.u.k. Kriegsmarine, 73.
} 


\section{Sažetak}

Političke promjene na europskom kontinentu sredinom 19. st. primorale su Habsburšku Monarhiju da koncentrira svoja vojno-financijska sredstva na istočnom Jadranu. Posljedica toga bio je razvoj Pule koja doživljava demografski i svaki drugi rast. Među pridošlicama bili su ljudi različitoga društvenog statusa, a među njima je svoje mjesto našao nadvojvoda Karlo Stjepan Habsburški. Nakon završetka Mornaričke akademije u Rijeci napredovao je u aktivnoj službi sve do čina kontraadmirala. Tada se povlači, a vrijeme u mirovini provodi često krstareći Jadranom i upravljajući svojim imanjem u Poljskoj. Tijekom Prvoga svjetskog rata preuzima funkciju pokrovitelja dobrotvornih udruga za prikupljanje pomoći u ratu, da bi pred kraj rata bio inspektor za istragu pobune mornara u Boki kotorskoj, čiji su savjeti utjecali na odluke cara Karla. Zbog čvrstih veza s Poljskom, bio je kandidat za njezinu krunu koju mu je nudio njemački car, ali ponudu nije prihvatio. Tijekom aktivne službe, a osobito u mirovini, nadvojvoda je pokazivao sklonost krstarenju Jadranom. Iz toga je razloga sagradio vile u Velom Lošinju, gdje mu se nalazila baza za krstarenje Jadranom, i Puli, kamo se preselio zbog potreba službe. Zaljubljenik u more i jahte, bio je sklon dizajniranju vlastitih jahti, a svoju je umjetničku stranu pokazivao ispunjavajući slobodno vrijeme slikanjem i sviranjem klavira. Pridonosio je društveno-kulturnom životu Pule svojom nazočnošću i organizacijom, a gradovima u kojima je boravio ostavio je u spomen svoje reprezentativne građevine.

\section{La presenza dell'arciduca Carlo Stefano sull'Adriatico}

\section{Riassunto}

I cambiamenti politici della metà del XIX secolo nel continente europeo costrinsero la Monarchia asburgica a concentrare le proprie risorse militari e finanziarie sul versante orientale dell'Adriatico. Come conseguenza si ebbe lo sviluppo di Pola sia sotto l'aspetto della crescita demografica sia sotto molti altri aspetti. Tra i nuovi arrivati furono persone di vario status sociale, tra cui anche l'arciduca Carlo Stefano d'Asburgo. Dopo aver frequentato l'Accademia Navale di Fiume, durante il suo servizio attivo progredì fino ad ottenere il grado di contrammiraglio, dopo di che si ritirò e trascorse il periodo di pensionamento facendo crociere per l'Adriatico e attendendo al proprio possedimento in Polonia. All'inizio della Prima guerra mondiale assunse come ammiraglio la funzione di patrocinante delle associazioni umanitarie per la raccolta degli aiuti in guerra, per diventare poi, verso la fine della guerra, ispettore nell'indagine dell'ammutinamento dei marinai nelle Bocche di Cattaro, i cui consigli influirono sulle decisioni dell'imperatore Carlo. Grazie ai forti legami con la Polonia, fu candidato alla sua corona, offertagli dall'imperatore tedesco. Ma l'offerta non fu accettata. Durante il servizio attivo, e specie in pensione, l'arciduca dimostrò una propensione verso le crociere nell'Adriatico. Per tale ragione costruì delle ville a Lussingrande, dove si trovava la sua base per le crociere, e a Pola, dove si trasferì per le necessità del suo servizio. Appassionato di mare e di yaht, mostrò un'inclinazione verso il design delle proprie yaht e l'espressione del suo lato 
artistico manifestò colmando il suo tempo libero con la pittura e le esecuzioni sul pianoforte. Con la sua presenza e organizzazione contribuì alla vita sociale e culturale di Pola, mentre nelle città in cui si soffermò, lasciò in ricordo degli edifici rappresentativi.

\section{Archduke Charles Stephen at the Adriatic Sea}

\section{Summary}

Political changes in the $19^{\text {th }}$ century Europe forced Habsburg Monarchy to channel their military and financial resources to the Eastern Adriatic. The consequence of these actions was the development of Pula, which experienced demographic and all other developments. Among the newcomers were people of all social classes, and one of the more prominent ones was Archduke Charles Stephen of Austria. After graduating from Naval Academy in Rijeka, he had advanced within officer ranks up to the rank of rear admiral. At that point he had retired, often spending his time sailing the Adriatic and governing his estate in Poland. During World War I he became the sponsor of charities responsible for collecting donations for the war, and by the end of the war he was the head inspector investigating the mutiny of sailors in Boka Kotorska, his counsel was the most influential on Emperor Charles I. Because of his ties to Poland, he was considered as the ruler of the country, he was offered the crown by the German Emperor; however, he had refused the offer. During his service, and especially later during retirement years, Archduke had the penchant for sailing the Adriatic. This is why he had built villas in Veli Lošinj, which he had made his base when sailing the Adriatic, and in Pula, where he had relocated due to his duties. Enamoured with the sea and yachts, he had a tendency for designing his own yachts, fulfilling his artistic inclinations by painting and playing the piano in his spare time. He had contributed to the culture and social life of Pula with his presence and arrangements, and to the cities which he inhabited, he had left his monumental edifices as a memento. 